\title{
Some anti-diabetic properties of Prosopis farcta extracts in alloxan induced diabetic in adult rats
}

\author{
I.H. Mohammed ${ }^{1}$, I.S. Kakey ${ }^{2}$ and M.M. Farimani ${ }^{3}$ \\ ${ }^{1}$ Department of Medical Microbiology, ${ }^{2}$ Department of Biology, Faculty of Science and Health, Koya University, Koya \\ KOY45, Kurdistan Region - F.R. Iraq; ${ }^{3}$ Department of Phytochemistry, Medicinal Plants and Drugs Research Institute, Shahid \\ Beheshti University, G. C., Evin, Tehran,Iran
}

Email: ${ }^{1}$ ismael.hasan@koyauniversity.org, ${ }^{2}$ esmail.kakey@koyauniversity.org, ${ }^{3}$ m_moridi@ sbu.ac.ir

(Received April 13, 2019; Accepted May 6, 2019)

\begin{abstract}
Prosopis farcta is belonged to Mimosaceae family, commonly known as mesquite. It was chosen to investigate their effect on $\alpha$-glucosidase inhibitory activity (in-vitro), serum glucose and liver functions. Roots, fruits, and leaves of $P$. farcta, were extracted by $n$-hexane, ethyl acetate, and methanol. $\alpha$-glucosidase inhibition was analyzed by using ELISA technique then half maximal inhibitory concentration IC $_{\mathbf{5 0}}$ was found. The blood glucose levels were determined with a glucose analyzer model. The serum alkaline phosphatase (ALP), Alanine transaminase (ALT), aspartate aminotransferase (AST) and serum total bilirubin (TB) were estimated by using the Cobas diagnostic kit with a fully automated chemical analyzer. Diabetes was done by a single dose of $120 \mathrm{mg}$ alloxan $/ \mathrm{kg} \mathrm{b} . \mathrm{w}$ with subcutaneously injection. Ethyl acetate extracts of $P$. farcta showed the higher $\alpha$-glucosidase inhibitory activity, and the best one was root extract. Treatments of the alloxan-induced diabetes rats were done by daily oral administration of different concentrations with $P$. farcta extracts of ethyl acetate for 28 days and the dose 200 $\mathrm{mg} / \mathrm{kg} \mathrm{BW}$ was the effective one. The root extract was the best one for reduction of serum glucose followed by leaves then fruits. Administration of root extract of P. farcta showed a decrease in the levels of ALP and TB in alloxan-induced diabetes rats. The fruit extract of $P$. farcta showed decreasing in the level of ALP in alloxan-induced diabetes rats. In conclusion, the $P$. farcta extracts for ethyl acetate have properties of hypoglycemic effect as well as improving some parameters related with diabetic complications of liver functions.
\end{abstract}

Keywords: Prosopis farcta, Diabetes, Rats

Available online at http://www.vetmedmosul.com, () 2020, College of Veterinary Medicine, University of Mosul.

This is an open access article under the CC BY 4.0 license (http://creativecommons.org/licenses/by/4.0/).

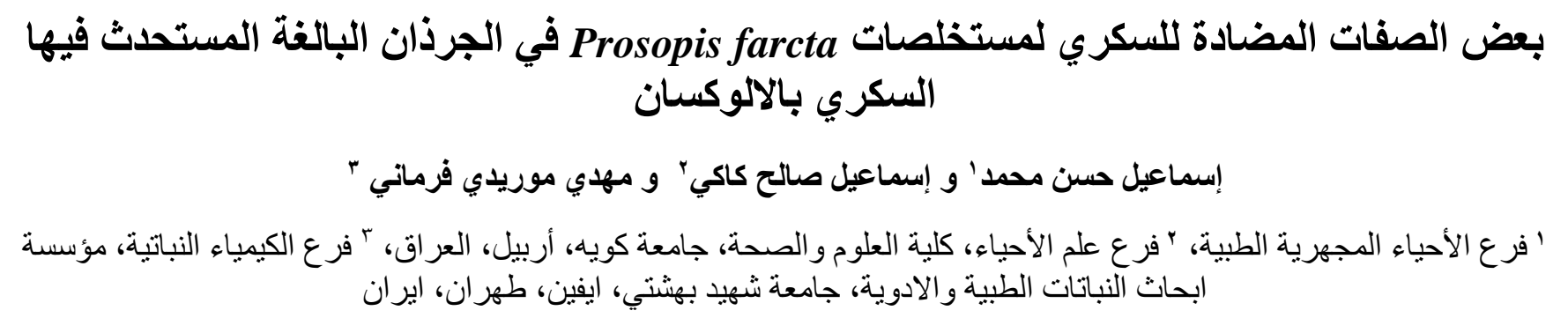

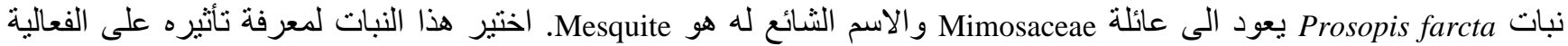

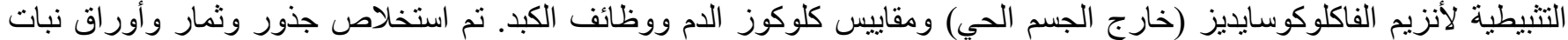
الينبوت بو اسطة الهكسان و الأثيل اسيتيت و الميثانول. قيست الفعالية التثبيطية لأنزيم الفاكلوكوسايديز باستعمال تقنية الاليز ا ومن ثم إيجاد

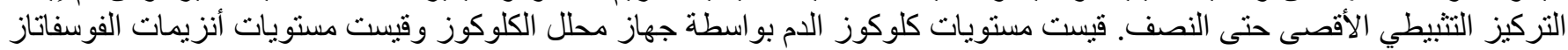

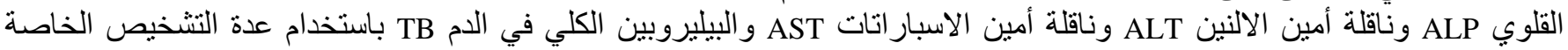




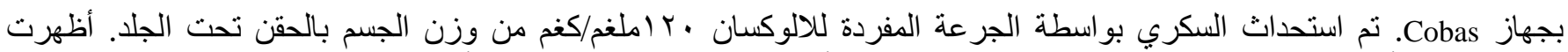

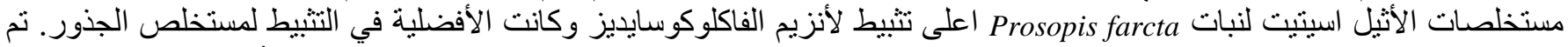

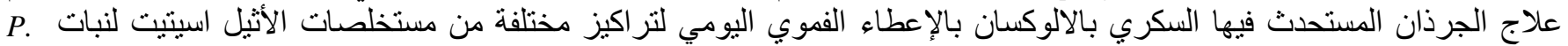

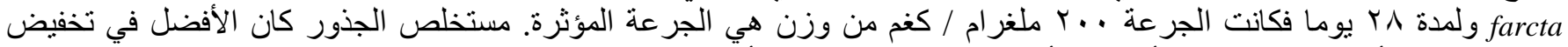

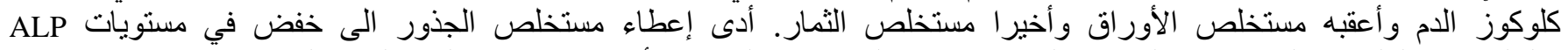

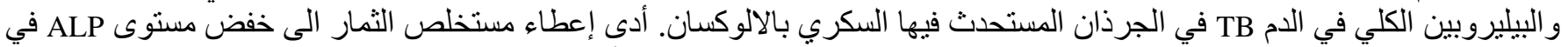

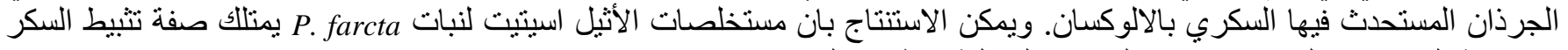

بالإضافة الى تحسينه لبعض نعقيدات السكري المتعلقة بوظائف الكبان الكبد.

\section{Introduction}

Diabetes is characterized by increasing the level of blood sugar due to insulin resistance, lack of insulin secretion or an abnormal increase of glucagon secretion $(1,2)$. At the level of villi of the small intestine wall the $\alpha$ glucosidase breaks down disaccharides to monosaccharides which is considered the end step of digestion of the sugars. Substances that inhibit $\alpha$-amylase and $\alpha$-glucosidase will prevent degradation of carbohydrates in the small intestine and decrease the postprandial blood glucose in the circulation (3). There is a good history of using P. farcta in the treatment of diabetes in traditional medicine because it contains an active compound such as daucosterol, epicatechin, $\beta$-sitosterol and lupeol that have antidiabetic effects $(4,5)$. P. farcta, commonly known as Syrian mesquite in Arabic countries and as Kahurak and Jeghjegheh in Iran, is a woody perennial dwarf legume, which has been distributed from India to Jordan. Different species of the Prosopis genus have been utilized for gum, paint and cordage (6) and as dietary supplements for feeding ruminants (7) as well as for medicinal purposes. Beans and leaves of $P$. farcta have traditionally been used for the treatment of some diseases and disorders such as diabetes $(8,9)$ healing lesions $(10)$, diarrhea, and colds $(11)$.

The liver is the main organ for the regulation of carbohydrate metabolism, as it uses glucose as a fuel, it has the capability to store glucose as glycogen and synthesize glucose from non-carbohydrate source. This key function of the liver makes it vulnerable to diseases related to metabolic disorders, particularly diabetes (12). Several biochemical tests are useful in the evaluation and management of patients with hepatic dysfunction. Liver Function Tests (LFTs) are used for indication of liver disease. The most common liver function tests include the serum aminotransferases (ALT, AST), alkaline phosphatase, bilirubin, and albumin. Increased activities of liver enzymes such as aspartate aminotransferase (AST), alanine aminotransferase (ALT) and $\gamma$-glutamyl transferase (GGT) are indicators of hepatocellular injury. Increased levels of these markers are associated with insulin resistance (13). We conducted this study to explain the effect of P. farcta on glucose levels, functions of the liver in type 1 diabetes.

\section{Materials and methods}

The roots, leaves, and fruits of $P$. farcta were collected from Koya in Erbil province, Iraq. The plant was identified in the Herbarium of Medicinal Plants and Drugs Research Institute, Shahid Beheshti University in Tehran-Iran.

The plant materials were dried at room temperature and ground by an electrical grinder, $10 \mathrm{~g}$ was extracted with 50 $\mathrm{ml}$ of each solvent and the solvents were $n$-hexane, ethyl acetate and methanol then macerated on a magnetic stirrer for $1 \mathrm{hr}$. The extracts were dryness by rotatory evaporator under reduced pressure at $45{ }^{\circ} \mathrm{C}$, finally, we got solid powder extracts. High concentration for extracts $1000 \mathrm{ppm}$ was used as stock solution for $\alpha$ - glucosidase assay (invitro) by adding $1.4 \mathrm{mg}$ of each extract to $1.4 \mathrm{ml}(1400 \mu \mathrm{L})$ of dimethyl sulfoxide (DMSO). The request volume of the extract solution for the alpha glucosidase assay was one micro litter from each extract samples. Different concentrations of extract samples were used in this assay. Enzyme Linked Immuno Sorbent Assay (ELISA) (CLARIO star Microplate Reader from BMG Labtech) was applied to do $\alpha$-glucosidase assay on extracts using the reaction mixture consisting $25 \mu \mathrm{L}$ of $2 \mathrm{mM} \mathrm{p}$-nitrophenyl $\alpha$ D-glucopyranoside (Sigma Chemical Co.), $49.5 \mu \mathrm{L}$ phosphate buffer ( $\mathrm{pH}$ 7.0) adding to flask contains $0.5 \mu \mathrm{L}$ of sample dissolved in DMSO at various concentrations 200-1000 ppm. The reaction mixture was pre-incubated for 5 minutes at $37^{\circ} \mathrm{C}$, the reaction was started by adding 25 $\mu \mathrm{L} \alpha$-glucosidase (Sigma) incubation was continued from 30 minutes. The reaction stopped by adding $1 \mathrm{ml}$ of $0.01 \mathrm{M}$ $\mathrm{Na}_{2} \mathrm{CO}_{3}$. The activity of $\alpha$-glucosidase was determined by measuring the release of p-nitro phenol at $400 \mathrm{~nm}$. Acarbose $\left(\right.$ Glucobay ${ }^{\circledR}$ ) positive control of $\alpha$-glucosidase. Inhibition of sample with $\alpha$-glucosidase activities was measured by increasing concentration of p-nitrophenyl $\alpha$-Dglucopyranoside as a substrate in the absence or presence of samples at different concentrations. Inhibition type was determined by Lineweaver-Burk plot analysis of the data, which were calculated from the result according to Michaelis of the data, which were calculated from the result according to Michaelis- Menten kinetics. $\alpha$-glucosidase 
inhibition \% inhibition has been obtained using the formula, $\%$ inhibition $=(1-$ average of sample slope/ average of enzyme slope) $\times 100$ (14) then IC $_{50}$ was found by formula of $\mathrm{y}=\mathrm{a} \mathrm{x}+\mathrm{b}$ where $\mathrm{y}=50$ and $\mathrm{a}, \mathrm{b}$ was found from the plot.

Albino rats male rats 1.5-2 months old that weighed 190-220 g with a mean weight of $200 \mathrm{~g}$. were used. Diabetes was induced by a single subcutaneous injection of $120 \mathrm{mg}$ alloxan/kg b.w and rats with blood glucose levels above $200 \mathrm{mg} / \mathrm{dl}$ were considered as diabetic rats (15).

Rats were randomly divided into six groups of seven each. Because extract of ethyl acetate for roots of Prosopis farcta showed the best inhibition for 50\% of alpha glucosidase activity, therefore it was selected for the next work to compare with an ethyl acetate extract for fruits and leaves of $P$. farcta as well as with the insulin. The extraction of in-vivo study for glucose and liver function parameters included mixing of $2 \mathrm{~kg}$ of each part of the $P$. farcta (roots, leaves, fruits) with 10 liters of the ethyl acetate and the procedure continued as mentioned above. Different concentrations 50,100, 150, 200, 250, $300 \mathrm{mg} / \mathrm{kg}$ of extracts were prepared by suspending the dried powder of each kind of the extracts in physiological saline.

The ethyl acetate extracts of $P$. farcta (roots, leaves, fruits) was orally administrated daily for 28 days with a different doses (concentrations) for each kind of extract. Group I, non-treated rats administered $1 \mathrm{ml}$ physiological saline; Group II alloxan-induced diabetic rats, administered $1 \mathrm{ml}$ physiological saline; Group III alloxan-induced diabetic rats, administered roots extract; Group IV alloxaninduced diabetic rats administered leaves extract ; Group V alloxan-induced diabetic rats administered fruits extract; and Group VI alloxan-induced diabetic rats subcutaneously injected with insulin (Actrapid. Novo Nordisk, Denmark) (10 I.U/Kg of body weight) (16).

The blood glucose levels were determined in-vivo with a glucose analyzer model (Contour ( ${ }^{\circ}$ TS, Bayer Pty, Ltd; Healthcare Division, Japan). The serum glucose was estimated by using the Cobas diagnostic kit with fully automated chemical analyzer (Cobas C 311). The serum ALP, ALT, AST and serum total bilirubin (TB) were estimated by using the Cobas diagnostic kit with a fully automated chemical analyzer (Cobas C 311 according to the manufacturer's protocol).

Table 2: Effect of Prosopis farcta extracts on serum glucose level in alloxan-induced diabetic rats

\begin{tabular}{lccccc}
\hline Animal groups & $\begin{array}{c}\text { Serum Glu. } \\
\text { Before treat. }\end{array}$ & $\begin{array}{c}1^{\text {st }} \text { week of } \\
\text { treat. }\end{array}$ & $\begin{array}{c}2^{\text {nd }} \text { week of } \\
\text { treat. }\end{array}$ & $\begin{array}{c}3^{\text {rd }} \text { week of } \\
\text { treat. }\end{array}$ & $\begin{array}{c}\text { Before T vs } 3^{\text {rd }} \\
\text { week P value }\end{array}$ \\
\hline Normal control rats & $92.00 \pm 4.461$ & $96.20 \pm 6.437$ & $93.00 \pm 5.831$ & $93.00 \pm 6.819$ & $\mathrm{NS}$ \\
Diabetic rats & $465.0 \pm 24.97$ & $495.0 \pm 24.60$ & $451.0 \pm 20.76$ & $446.0 \pm 17.20$ & $\mathrm{NS}$ \\
Diabetic rats + root extract & $448.0 \pm 30.36$ & $284.0 \pm 15.03$ & $286.0 \pm 10.77$ & $176.2 \pm 8.375$ & 0.001 \\
Diabetic rats + leaves extract & $448.0 \pm 28.04$ & $304.0 \pm 10.30$ & $290.0 \pm 7.071$ & $274.0 \pm 9.274$ & 0.05 \\
Diabetic rats + fruits extract & $465.0 \pm 25.00$ & $306.0 \pm 12.08$ & $291.0 \pm 6.403$ & $300.0 \pm 10.49$ & 0.001 \\
Diabetic rats + insulin & $467.0 \pm 22.51$ & $153.0 \pm 13.38$ & $132.0 \pm 11.47$ & $112.4 \pm 5.501$ & 0.0001 \\
\hline
\end{tabular}

Results express as mean \pm SEM. Glucose was measured by $\mathrm{mg} / 100 \mathrm{ml}$.

\section{Statistical analysis}

SPSS version 24 statistical software was used to analyze the data. The ANOVA analysis was used to investigate the relationship of the parameters. Probability level of $\mathrm{P}$ value $(\mathrm{P}<0.05)$ level of significance was considered to be statistically significant.

\section{Results}

The results of the in vitro study, revealed that ethyl acetate extract for roots of $P$. farcta extract showed the best inhibition for $50 \%$ of $\alpha$ - glucosidase activity (IC50) and it was better than acarbose $16.5 \mu \mathrm{g} / \mathrm{ml}$ (Table 1).

Table 1: $\mathrm{IC}_{50}(\mu \mathrm{g} / \mathrm{ml})$ values for $\alpha$-glucosidase inhibition activity of $P$. farcta extracts

\begin{tabular}{lcrc}
\hline Extracts & n-hexane & Ethyl acetate & Methanol \\
\hline Roots & $>125$ & $10.9 \pm 1.03 \mathrm{a}$ & $26.4 \pm 1.42 \mathrm{~b}$ \\
Fruits & $>125$ & $68.1 \pm 2.11 \mathrm{c}$ & $59.8 \pm 1.9 \mathrm{~d}$ \\
Leaves & $>125$ & $54.7 \pm 2.02 \mathrm{e}$ & $40.1 \pm 1.16 \mathrm{f}$ \\
Acarbose & $16.5 \pm 1.12 \mathrm{~g}$ & & \\
\hline
\end{tabular}

Data are presented as mean \pm SD values of triplicate determination. Different letters for a given value within a column are significantly different from each other $(\mathrm{P}<0.05)$. SEM: Standard Error Mean; IC50: Half-maximal inhibitory concentration.

Table 2 elucidates the effects of Prosopis farcta extracts on serum glucose level in normal and diabetic male rats. Incidence of diabetes caused hyperglycemia in the rats. Among the extracts effects, the root extract was more reduced to the glucose. The highest reduction was in the third week of administration of the root extract as compared with other two extracts in diabetic rats, but their hyperglycemic effect was less than effect of insulin. The second one was leave extract then the extract of fruits. Also, the reduction of glucose was better in third week in these two kinds of extract as compared to other weeks. 
Table 3 elucidates the changes of effect of Prosopis farcta extracts $200 \mathrm{mg} / \mathrm{kg}$ of body weight on the liver functions test parameters in normal and alloxan induced diabetic rats. ALP decreased in diabetic rats compared with normal rats. Root and fruit extracts decreased the enzyme of ALP in diabetic rats compared with control diabetic rats. There was no significant difference between them. Decreasing of insulin was higher than both extracts. AST and ALT showed increasing in their levels in diabetic rats. No extracts could do any changes in the level of AST and ALT. Unlike insulin, that showed a reduction in the levels of both enzymes in diabetic rats compared with control diabetic rats. Total serum bilirubin increased in diabetic rats comparing with the normal control rats. Root extract and insulin showed reduction in level of total serum bilirubin in diabetic rats compared with those in control diabetic rats.

Table 3: Changes in the liver markers by $P$. farcta roots, leaves and fruits extracts in alloxan induced-diabetic rats

\begin{tabular}{lcccccc}
\hline liver & \multicolumn{2}{c}{ Control groups } & \multicolumn{4}{c}{ Treatment group (Diabetic rats) } \\
\cline { 2 - 6 } markers & Normal rats & Diabetic rats & Roots extract & Leaves Extract & Fruits Extract & Insulin \\
\hline ALP & $143.1 \pm 11.35^{\mathrm{a}}$ & $242.9 \pm 11.51^{\mathrm{c}}$ & $195.9 \pm 5.241^{\mathrm{b}}$ & $218.3 \pm 5.052^{\mathrm{bc}}$ & $200.0 \pm 10.80^{\mathrm{b}}$ & $157.1 \pm 4.199^{\mathrm{a}}$ \\
AST & $44.06 \pm 8.622^{\mathrm{a}}$ & $109.1 \pm 7.435^{\mathrm{c}}$ & $98.82 \pm 12.20^{\mathrm{bc}}$ & $94.64 \pm 2.833^{\mathrm{bc}}$ & $80.69 \pm 4.557^{\mathrm{abc}}$ & $60.25 \pm 4.727^{\mathrm{ab}}$ \\
ALT & $55.02 \pm 2.100^{\mathrm{ab}}$ & $80.28 \pm 2.163^{\mathrm{c}}$ & $75.68 \pm 1.875^{\mathrm{c}}$ & $76.81 \pm 1.190^{\mathrm{c}}$ & $75.28 \pm 1.670^{\mathrm{c}}$ & $65.88 \pm 2.307^{\mathrm{b}}$ \\
Bilirubin & $0.320 \pm 0.019^{\mathrm{a}}$ & $1.632 \pm 0.145^{\mathrm{c}}$ & $0.904 \pm 0.064^{\mathrm{b}}$ & $1.202 \pm 0.036^{\mathrm{bc}}$ & $1.206 \pm 0.036^{\mathrm{bc}}$ & $1.132 \pm 0.198^{\mathrm{b}}$ \\
\hline
\end{tabular}

Results expressed as Mean \pm St. error. The same letters mean non-significant difference, while the different letters mean significant difference at $\mathrm{P}<0.05$.

\section{Discussion}

Ethyl acetate extract for roots, leaves and fruits of $P$. farcta, showed most effective inhibition of $\alpha$-glucosidase and the ethyl acetate extract the roots of $P$. farcta was the best one for reduction of serum glucose in vivo. This effect may use in ease the risk of the post-prandial phase. This phase occurs after breaking down of disaccharides by alpha-glucosidase enzymes which located in the brush border of the enterocytes of the jejunum in the small intestine; they are immediately absorbed by capillaries in the upper jejunum causing hyperglycemia (17). Alpha glucosidase inhibitors compete with binding of disaccharides with alpha glucosidase enzymes so will prevent binding of them that will lead prevent cleavage to monosaccharides then prevent or slow entrance in the bloodstream and finally reduce post-prandial blood glucose level (18). Herbs like Cyperus rotundus, Plumbago zeylanica, Symplocos racemosa and Terminalia arjuna contain a component such as alkaloid, terpene, saponin, tannin, glycoside, flavonoid, and quinone have a high ability to inhibit alpha-glucosidase with minimum quantities and side effects as well as at the lowest cost $(19,20)$.

Alloxan has been found to be selectively toxic to pancreatic beta cells as it preferentially accumulates in the beta cells as glucose analogues preventing insulin production leading to hyperglycemia. In addition, the cytotoxic action of alloxan is mediated mainly by the generation of reactive oxygen species (ROS) (21). The obtained results in this study revealed that diabetes induced by alloxan induced significant increases in the serum levels of ALP, AST and ALT. These enzymes are evidence of liver cells injury and leakage of enzymes from cells (22). Also, they are considered enzyme biomarkers to monitor the liver status and aid to demonstrate the liver toxicity conditions (23). Furthermore, diabetic complications such as increase of gluconeogenesis and ketogenesis refers to the increase in the levels of these enzymes (24). Treatment with insulin decreased level all those enzymes in diabetic rats. The diabetic case is represented with hyperglycemia that is associated with liver injury, as indicated by elevated levels of ALP, AST, and ALT, treatment with insulin will decrease the hyperglycemia, improve case of liver and decrease those enzymes level $(25,26)$. Administration of $P$. farcta extracts (Root and fruit) caused a detectable decrease of ALP in diabetic rats thus improving hepatic function. Similar results were reported by many authors for role of olive leaves extracts in improving hepatic function (27-30). In addition to what the artificial induction of diabetes is doing in body changes including liver, hyperglycemia has been found to play a key role in ROS generated damage (31). Reduction of this enzyme level may be through the ability of $P$. farcta to reduce sugar in diabetic rats that leads to normalizing the liver function including this enzyme (25). Total serum bilirubin increased in diabetic rats compared with the normal control rats. Diabetes can affect many parts of the body and is associated with serious complications. Oxidative stress is a major contributor in the pathogenesis of diabetic complications and bilirubin has been shown to have antioxidant effects so will increase its level in diabetic case (32). Insulin showed a reduction in the level of total serum bilirubin in diabetic rats. The characteristic sign of diabetes is hyperglycemia that plays a key role in ROS generated damage (31). High ROS ratios will be associated with an increase in antioxidant levels 
including bilirubin level (32). So, diminishing of hyperglycemia by insulin will lower levels of ROS and thus reduce the level of antioxidants including bilirubin. Maybe, in the same way, the root extract of P. farcta can reduce the bilirubin level.

\section{Conclusion}

We concluded from this study that Prosopis farcta extracts especially root extract could improve serum glucose and some liver function parameters in diabetic rats that may suggest it to use as a medicine against diabetes.

\section{Acknowledgments}

Thanks to God. I appreciate and thank to Department of Biology, College of Science, University of Salahuddin, Erbil, Iraq.

\section{References}

1. Eddouks M, Bidi A, El Bouhali B, Hajji L, Zeggwagh N. Antidiabetic plants improving insulin sensitivity. J Pharm Pharmacol. 2014;66(9):1197-1214. doi: 10.1111/jphp.12243.

2. Cryer P. Minireview: Glucagon in the pathogenesis of hypoglycemia and hyperglycemia in diabetes. Endocrinol. 2012;153(3):1039-1048. doi:10.1210/en.2011-1499

3. Telagari M, Hullatti K. In-vitro $\alpha$-amylase and $\alpha$-glucosidase inhibitory activity of Adiantum caudatum Linn. and Celosia argentea Linn. Extracts and fractions. Indian J Pharmacol. 2015;47(4):425-429. DOI: $10.4103 / 0253-7613.161270$.

4. Said O, Khalil K, Fulder S, Azaizeh H. Ethnopharmacological survey of medicinal herbs in Israel, the golan heights and the west bank region. J Ethnopharmacol. 2002;83(3):251-265. DOI: 10.1016/s03788741(02)00253-2.

5. Dashtban M,Sarir H,Omidi A.The effect of Prosopis farcta beans extract on blood biochemical parameters in streptozotocin- induced diabetic male rats. Adv Biomed Res. 2016; 5:116. DOI:10.4103/22779175.185575.

6. Orozco - Villafuerte J, Cruz-Sosa F, Ponce-Alquicira E, VernonCarter E. Mesquite gum: Fractionation and characterization of the gum exuded from Prosopis laevigata obtained from plant tissue culture and from wild trees. Carbohydrate Polymers. 2003;54:327333. DOI: 10.1016/S0144-8617(03)00187-5.

7. Andrade-Montemayor H, Cordova-Torres A, García-Gasca T, Kawas J. Alternative foods for small ruminants in semiarid zones, the case of Mesquite (Prosopis laevigata spp.) and Nopal (Opuntia spp.). Small Rumin Res. 2011;98:83-92. DOI: 10.1016/j.smallrumres.2011.03.023.

8. Hamdan I, Afifi F. Studies on the in vitro and in vivo hypoglycemic activities of some medicinal plants used in treatment of diabetes in Jordanian traditional medicine. J Ethnopharmacol. 2004;93:117-121. DOI: $10.1016 /$ j.jep.2004.03.033.

9. Al-Aboudi A, Afifi FU. Plants used for the treatment of diabetes in Jordan: A review of scientific evidence. Pharm Biol. 2011;49:221239. DOI: $10.3109 / 13880209.2010 .501802$.

10. Ranjbar-Heidari A, Khaiatzadeh J, Mahdavi-Shahri N, Tehranipoor M. The effect of fruit pod powder and aquatic extract of Prosopis farcta on healing cutaneous wounds in diabetic rat. Zahedan J Res Med Sci. 2012;14:16-20.

11. Saidi MR, Farzaei MH, Miraghaee S, Babaei A, Mohammadi B, Bahrami MT. Antihyperlipidemic effect of Syrian Mesquite (Prosopis farcta) root in high cholesterol diet-fed rabbits. J Evid Based
Comp Alter Med. 2016; 21(4): 62-66. DOI: 10. 1177 /2156 587215 627552.

12. Levinthal GN, Tavill AJ. Liver disease and diabetes mellitus. Clin Diabetes. 1999;17:73.

13. Marchesine G, Brizi M, Bianchi G. Non-alcoholic fatty liver disease: A feature of metabolic syndrome. Diab. 2001;50:1844-1850. DOI: $10.2337 /$ diabetes.50.8.1844.

14. Yingbo Y, Lihua G, Ying X, Qing L, Haijun Hu, Zhengtao W, Kaixian C. Rapid Identification of $\alpha$-Glucosidase Inhibitors from Phlomis tuberosa by Sepbox Chromatography and Thin-Layer Chromatography Bioautography. PLoS One. 2015;10(2):0116922. DOI: 10.1371/journal.pone.0116922.

15. Szkudelski T. The mechanism of alloxan and streptozotocin action in $\beta$ - Cells of the rat pancreas. Physiol Res. 2001;50(6):536-546.

16. Ukwenya VO, Ashaolu OJ, Adeyemi DO, Abraham KJ. Experimental diabetes and the epididymis of Wistar rats: The protective effects of Anacardium occidentale (Linn.). J Exp Clin Anatomy. 2015;14:5762. DOI: $10.4103 / 1596-2393.177029$.

17. Puls W, Krause H, Muller L. Inhibitors of the rate of carbohydrate and lipid absorption by the intestine. Int J Obes. 1984;8(1):181-90.

18. Fonseca V. Clinical significance of targeting post-prandial and fasting hyperglycemia in managing type 2 diabetes mellitus. Curr Med Res Opin. 2003;19(7):635-641. DOI: 10.1185/030079903125002351.

19. Hollander P. Safety profile of acarbose, an alpha-glucosidase inhibitor. Drugs. 1992; 44 (3): 47-53. DOI: 10.2165/00003495199200443-00007.

20. Ankita B, Mohamed S, Kavitha T. Screening of fifteen Indian ayurvedic plants for alpha- glucosidase inhibitory activity and enzyme kinetics. Inter J Pharma Pharmaceut Sci. 2011;3(4):267-274.

21. Rohilla A, Ali S. Alloxan induced diabetes: Mechanisms and effects. Inter J Res Pharmaceut Biomed Sci. 2012;3(2):819-823.

22. Bashandy S, Al Wasel S. Carbon tetrachloride-induced hepatotoxicity and nephrotoxicity in rats: Protective role of vitamin C. J Pharmacol Toxicol. 2011;6(30):283-292. DOI:10.3923/jpt.2011.283.292.

23. Amin A, Hamza AA. Oxidative stress mediates drug-induced hepatotoxicity in rats a possible role of DNA fragmentation. Toxicol. 2005;208(3):367-375.DOI: 10.1016/j.tox.2004.11.039

24. Monday MO, Uzoma IA. Histological changes and antidiabetic activities of Icacina trichantha tuber extract in beta-cells of alloxan induced diabetic rats. Asian Pacific J Trop Biomed. 2013;3(8):628633. DOI: $10.1016 / \mathrm{S} 2221-1691(13) 60127-6$.

25. Jeon CY, Roberts CK, Crespi CM, Zhang ZF. Elevated liver enzymes in individuals with undiagnosed diabetes in the US. J Diab Compl. 2013;27(4):333-339. DOI: 10.1016/j.jdiacomp.2013.04.005.

26. Nolasco E, Zanoni F, Nunes F, Ferreira S, Freitas L, Silva M, Martins J. Insulin modulates liver function in a type I diabetes rat model. 2015;30(4):1467-1479. DOI.org/10.1159/000430311.

27. Domitrovic R, Jakovac H, Marchesi V, Sain I, Romic Z, Rahelic D. Preventive and therapeutic effects of oleuropein against carbon tetrachloride-induced liver damage in mice. Pharmacol Res. 2012;65(4):451-464.DOI: 10.1016/j.phrs.2011.12.005.

28. Eidi A, Eidi M, Darzi R. Antidiabetic effect of Oleaeuropaea L. in normal and diabetic rats. Phytother Res. 2009;23(3):347-50. DOI: $10.1002 /$ ptr.2629

29. Kim SW, Hur W, Li TZ, Lee YK, Choi JE, Hong SW, Lyoo KS, You CR, Jung ES, Jung CK, Park T, Um SJ, Yoon SK. Oleuropein prevents the progression of steatohepatitis to hepatic fibrosis induced by high-fat diet in mice. Exp Mol Med. 2014;46(4):e92. DOI : 10 . 1038 /emm.2014.10.

30. Mousa HM, Farahna M, Ismail MS, Abdel-Salam AM. Anti-diabetic effect of olive leaves extract in alloxan-diabetic rats. J Agri Vet Sci. 2014;7(2):183-192. DOI: 10.12816/0009472.

31. Maritim AC, Sanders RA, Watkins JB. Diabetes, oxidative stress and antioxidants: A review. J Biochem Mol Toxicol. 2003;17(1):24-38. DOI: $10.1002 /$ jbt. 10058 . 
Iraqi Journal of Veterinary Sciences, Vol. 34, No. 1, 2020 (109-113)

32. Zhu B, Wu X, Bi Y, Yan Y. Effect of bilirubin concentration on the risk of diabetic complications: A meta-analysis of epidemiologic studies. Sci Rep. 2017;7(41681):1-15.DOI.org/10.1038/srep41681. 